\title{
MORPHOLOGY AND FRACTAL DIMENSION OF TiO, THIN FILMS
}

\section{Srđan Petrović1, Ljiljana Rožić1, Boško Grbić1, Nenad Radić1, Jasmina Dostanić1, Stevan Stojadinović ${ }^{2}$, Rastko Vasilić ${ }^{3}$}

\author{
${ }^{1}$ IChTM - Department of Catalysis and Chemical Engineering, \\ University of Belgrade, Njegoševa 12, 11000 Belgrade, Republic of Serbia \\ ${ }^{2}$ Faculty of Physics, University of Belgrade, \\ Studentski trg 12-16, 11000 Belgrade, Republic of Serbia \\ ${ }^{3}$ Faculty of Environmental Governance and Corporate Responsibility, \\ Educons University, Vojvode Putnika 87, Sremska Kamenica, Republic of Serbia
}

The influence of annealing temperature on the morphology and surface fractal dimension of titanium dioxide $\left(\mathrm{TiO}_{2}\right)$ films prepared via the spray deposition process was investigated. Thin films with various morphologies were obtained at different temperatures and characterized by X-ray diffraction and atomic force microscopy (AFM). It was found that the crystalline structure of $\mathrm{TiO}_{2}$ films depends strongly on annealing temperature. At higher temperatures, the partial phase transformation of anatase-to-rutile was observed. The morphology and surface fractal dimensions were evaluated by image analysis methods based on AFM micrographs. The results indicate that the value of surface roughness (the standard deviation of the height values within the given area of AFM image) of $\mathrm{TiO}_{2}$ films increases with increasing annealing temperature. Fractal analysis revealed that the value of the fractal dimension of the samples decreases slowly from 2.23 to 2.15 following the annealing process.

Keywords: fractal characteristic; surface morphology; $\mathrm{TiO}_{2}$ thin films; atomic force microscopy; spray deposition

\section{МОРФОЛОГИЈА И ФРАКТАЛНА ДИМЕНЗИЈА НА ТЕНКИ ФИЛМОВИ ОД ТіО}

Испитувано е влијанието на температурата на калење врз морфологијата и димензијата на површинскиот прелом на филмови од $\mathrm{TiO}_{2}$ подготвени преку процес на спреј пиролиза. Добиени се тенки филмови со различна морфологија на различни температури и се карактеризирани со дифракција на X-зраци и атомска микроскопија (AFM). Утврдено е дека кристалната структура на филмовите од $\mathrm{TiO}_{2}$ особено зависи од температурата на калење. На повисоки температури е забележена парцијална фазна трансформација од анатас во рутил. Морфологијата и димензијата на површинскиот прелом се проценети врз основа на методи на анализа базирани на AFM-микрографија. Резултатите укажуваат дека вредноста на рапавоста на површината (стандардната девијација на вредностите на висината е во рамките на дадена област на AFM-микрографијата) на филмовите од $\mathrm{TiO}_{2}$ се зголемува со зголемување на температурата на калење. Анализата на преломите покажува дека по процесот на калење вредноста на димензијата на површинскиот прелом на примероците полека се намалува од 2,23 до 2,15.

Клучни зборови: фрактални карактеристики; површинска морфологија; тенки филмови од $\mathrm{TiO}_{2}$; атомска микроскопија; спреј пиролиза 


\section{INTRODUCTION}

Metal oxides on metal or metal oxide substrates are of great importance in physics and heterogeneous catalysis. The activity and selectivity of any catalyst is influenced greatly by its physical properties at the interface between the substrate and the active phase. Titanium dioxide $\left(\mathrm{TiO}_{2}\right)$ deposited on different substrates (glass, quartz, stainless steel, titanium metal, and zeolites) is a catalyst of huge practical interest [1, $2,3]$. Many studies have shown clearly that a large surface area and well-defined crystallinity are prerequisites for a good photocatalyst $[4,5]$. Furthermore, the morphology of the $\mathrm{TiO}_{2}$ films prepared by various methods is a crucial factor in photocatalytic processes because of its close relation to heat and mass transfer and surface reaction [6]. The versatility of preparation procedures, such as sol-gel deposition [7, 8], spray pyrolysis [9], pulsed laser deposition [10], chemical vapor deposition [11], and magnetron sputtering [12] has led to a wide variety of structural and morphological characteristics of the obtained thin film catalysts. Therefore, it is not easy to characterize objectively the surface morphology by just applying standard characterization parameters, such as specific surface area, pore size distribution, and pore volume. Consequently, it is extremely important to define the relationship between the parameters applied to obtain the thin films, their structure, usable properties, and their fractal geometry [8, 12, 13, 14]. Fractal dimension is a parameter used to assess quantitatively the fractal geometry, and it represents a measure of the irregularity on the surface of a solid. Fractal patterns in nature are scale-dependent and have dimensions that are non-integral (unlike Euclidean geometry) and are independent of the scale of measurement. A fractal surface has a so-called Hausdorff-Besicovitch dimension D (also known as fractal dimension), restricted by $2 \leq \mathrm{D} \leq 3$, whereas a Euclidean (flat) surface has $\mathrm{D}=2$ [15].

Atomic force microscopy (AFM) is a particularly suitable tool for fractal analysis, because it yields quantitative surface measurements on scales ranging from angstroms to a few hundred microns $[15,16]$. AFM can provide a $2 \mathrm{D}$ profile of the surface, which is very useful for characterizing surface roughness, observing surface defects, and determining the size and conformation of molecules and aggregates on the surface $[17,18]$. The roughness factor (ratio of the real surface area to the geometrical surface projection) of a $\mathrm{TiO}_{2}$ film is important in the field of heterogeneous catalysis [19, 20].

In this study, $\mathrm{TiO}_{2}$ (Degussa-P25) films were deposited by spray deposition on a stainless steel substrate. Samples were further annealed at different temperatures to study the effect of annealing on surface morphology. AFM was used to scan and analyze the roughness and fractal dimension of the surface of the $\mathrm{TiO}_{2}$ films.

\section{EXPERIMENTAL}

Commercial $\mathrm{TiO}_{2}$, Degussa-P25 powder (80\% anatase $+20 \%$ rutile), was used for preparation of an aqueous solution $\left(\mathrm{TiO}_{2}\right.$ suspension $0.022 \mathrm{~mol} / \mathrm{l})$. A stainless steel foil, Sandvik OC 404, was used as the substrate. The initial temperature of the substrate was $460{ }^{\circ} \mathrm{C}$. $\mathrm{TiO}_{2}$ thin films supported on stainless steel foil were prepared by the spray deposition method. The spray pyrolysis apparatus and procedure used for preparing films immobilized on stainless steel is similar to that reported in a previously published study [21]. The equipment for spray deposition consists of a two-fluid glass nozzle (made of Pyrex glass with a diameter of $0.2 \mathrm{~mm}$ ), $\mathrm{TiO}_{2}$ suspension feeder, substrate heater, and a temperature controller. Atomization of the $\mathrm{TiO}_{2}$ suspension is achieved by airflow introduced to the outer glass tube, at a flow rate of $300 \mathrm{l} / \mathrm{h}$. The nozzle was part of a homemade computer-controlled device that enables nozzle movement with adjustable speed and direction. As-prepared multilayered $\mathrm{TiO}_{2}$ thin films were annealed in a tube furnace in a temperature range of 500 to $700{ }^{\circ} \mathrm{C}$. 
The crystal phase composition of the $\mathrm{TiO}_{2}$ films deposited on the stainless steel was determined by X-ray diffraction (Phillips PW 1050 powder) by using a diffractometer with Ni-filtered $\mathrm{CuK}_{\alpha}$ radiation $(40 \mathrm{kV}, 30 \mathrm{~mA}$, $\lambda=1.54178 \AA$ ). Diffraction patterns of both anatase and rutile powders were compared with reference [22] to the Crystallography Open Database.

The surface morphology of the samples was investigated by AFM (Veeco Instruments, model Dimension V). Micrographs were obtained in tapping mode under ambient conditions using Tap300 tips (resonance frequency $300 \mathrm{kHz}$, force constant $40 \mathrm{~N} / \mathrm{m}$ ). Roughness data were obtained by using diNanoScope software (version 7.0) and reported values are calculated mean values for a number of different samples obtained under the same conditions. The fractal dimension of the surface of the $\mathrm{TiO}_{2}$ thin films was calculated using the Image J $1.45 \mathrm{~s}$ software by using the Shifting Differential Box Counting (SDBC) plug-in.

The photocatalytic activity of the prepared $\mathrm{TiO}_{2}$ films was evaluated by using arylazo pyridone dye. The concentration of dye solution was $3.0 \mathrm{mg} / \mathrm{l}$. The volume of dye solution in all experiments was $100 \mathrm{ml}$. The temperature was $30{ }^{\circ} \mathrm{C}$. The mass of the $\mathrm{TiO}_{2}$ on the foil was $4.5 \mathrm{mg}$. The irradiation was performed using an Osram Vitalux lamp with a power consumption of $300 \mathrm{~W}$, housed $50 \mathrm{~cm}$ above the top surface of the dye solution. A Thermo Electron Nicolet Evolution 500 was used to measure absorption peak at $439 \mathrm{~nm}$.

\section{RESULTS AND DISCUSSION}

The crystal phase composition of the $\mathrm{TiO}_{2}$ films coated on stainless steel and those annealed at temperatures of 500,600, and $700{ }^{\circ} \mathrm{C}$ are presented in Figure 1. XRD patterns show clearly that the main peak for all samples is at $2 \theta=25.48^{\circ}$, which corresponds to the anatase (101) plane. In addition, the presence of other crystallographic planes was observed:
(200) and (201) corresponding to anatase, and (110), (101), (121), (002), and (130) corresponding to the planes of the rutile phase. When the annealing temperature was increased to $600{ }^{\circ} \mathrm{C}$, the intensity of the $(130)$ rutile peak increased significantly, whereas there was no change in the intensity of the (110) rutile peak. The rutile plane (110) is not seen clearly in these patterns because the relatively low annealing temperatures cannot lead to anatase-to-rutile crystal transformation and the ratio of the rutile phase in Degussa-P25 powders is relatively low $(20 \%)$. The increase in the intensity of the (130) rutile diffraction peak was attributed to the increased crystallinity of the samples. Further annealing of the samples at $700{ }^{\circ} \mathrm{C}$ caused a change in the observed diffraction pattern and showed diffraction peaks corresponding to the (101), (200), and (201) planes of the anatase phase, and peaks corresponding to the (110), (101), (121), (002), and (130) planes of the rutile phase of $\mathrm{TiO}_{2}$.

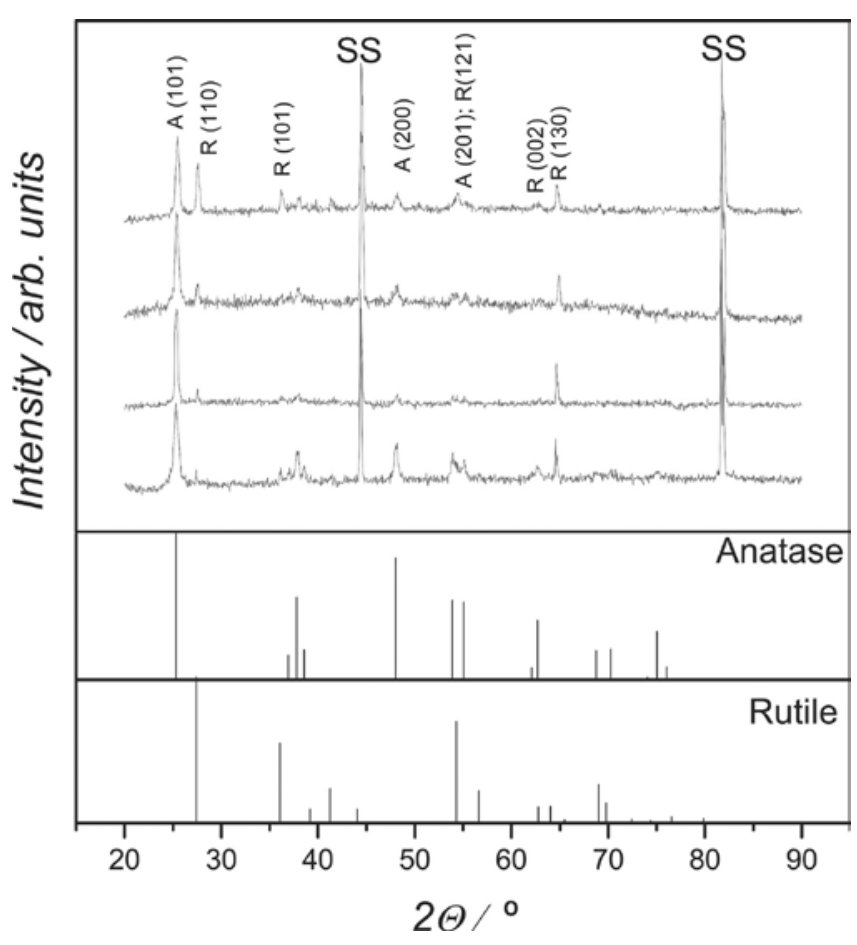

Fig. 1. XRD patterns of as-prepared and annealed $\mathrm{TiO}_{2}$ films, from bottom up: 500, 600, and $700{ }^{\circ} \mathrm{C}$, $\mathrm{A}=$ anatase, $\mathrm{R}=$ rutile, $\mathrm{SS}=$ stainless steel 
The estimated anatase-to-rutile ratio and crystallite size of each phase of the $\mathrm{TiO}_{2}$ films at different annealing temperatures are presented in Table 1 . The anatase (101) peak at $2 \theta=$ $25.48^{\circ}$ and rutile $(110)$ peak at $2 \theta=27.58^{\circ}$ were analyzed using the formula [23]:

$$
X=\left(1+0.8 \frac{I_{A}}{I_{R}}\right)^{-1}
$$

where $X$ is the weight fraction of rutile in the film, and $I_{A}$ and $I_{R}$ are the X-ray intensities of the anatase and rutile peaks, respectively.

The obtained results show that the crystalline structure of the $\mathrm{TiO}_{2}$ films is de- pendent on annealing temperature. As the annealing temperature increases from 600 to $700{ }^{\circ} \mathrm{C}$, the anatase phase transforms partially into the more stable rutile form.

The crystallite size was calculated using full width at half maximum of intense diffraction peaks of anatase (101) and rutile (110) according to Scherrer's equation,

$$
D=\frac{(0.9 \times \lambda)}{\beta \cos \theta},
$$

where $D$ is the crystallite size in $\mathrm{nm}, \lambda$ is the wavelength of the incident X-rays in $\mathrm{nm}, \theta$ is the Bragg angle, and $\beta$ is full width at half maximum in radians.

$\mathrm{Tab} 1 \mathrm{e} 1$

Anatase-rutile ratio and crystallite size of anatase and rutile phase of the $\mathrm{TiO}_{2}$ films annealed at various temperatures

\begin{tabular}{cccccc}
\hline \hline Film & $\begin{array}{c}\text { Annealing } \\
\text { temperature } \\
\left({ }^{\circ} \mathrm{C}\right)\end{array}$ & $\begin{array}{c}\text { Anatase } \\
\text { crystallite size } \\
(\mathrm{nm})\end{array}$ & $\begin{array}{c}\text { Rutile } \\
\text { crystallite size } \\
(\mathrm{nm})\end{array}$ & $\begin{array}{c}\text { Weight fraction } \\
\text { of anatase } \\
(\%)\end{array}$ & $\begin{array}{c}\text { Weight fraction } \\
\text { of rutile } \\
(\%)\end{array}$ \\
\hline As prepared & 460 & 23.36 & - & 80.8 & 19.2 \\
$\mathrm{TiO}_{2}(\mathrm{P} 25)_{500}$ & 500 & 21.57 & - & 80.2 & 19.8 \\
$\mathrm{TiO}_{2}(\mathrm{P} 25)_{600}$ & 600 & 19.70 & 22.60 & 77.8 & 22.2 \\
$\mathrm{TiO}_{2}(\mathrm{P} 25)_{700}$ & 700 & 19.13 & 22.95 & 57.4 & 42.6 \\
\hline \hline
\end{tabular}

From the obtained data, we can see that a small decrease in the anatase crystallite size was observed after annealing across the entire temperature range from 500 to $700{ }^{\circ} \mathrm{C}$. On the other hand, in the case of rutile, only a negligible increase in crystallite size was observed. At the lower temperatures of 500 and $600{ }^{\circ} \mathrm{C}$, the weight fraction of rutile is unchanged and corresponds to the starting material. Only at $700{ }^{\circ} \mathrm{C}$ is there a significant increase in the proportion of the rutile phase, increasing to $42.6 \%$. The topography of the $\mathrm{TiO}_{2}$ thin films deposited on stainless steel foil is presented in Figure 2.
The surface of the as-prepared and annealed samples is decorated by agglomerated grains having considerable surface roughness. The samples annealed at higher temperatures exhibit a rough surface texture with high mountains and deep valleys generated by the fusion of particles at inter particle contacts. The evaluation of surface roughness is performed via the mean roughness $\left(\mathrm{R}_{\mathrm{a}}\right)$ and root mean square roughness $\left(\mathrm{R}_{\mathrm{q}}\right)$, which are important parameters used to describe the surface roughness by statistical methods [8].

The values of both $R_{a}$ and $R_{q}$ of the asprepared samples increase significantly with 

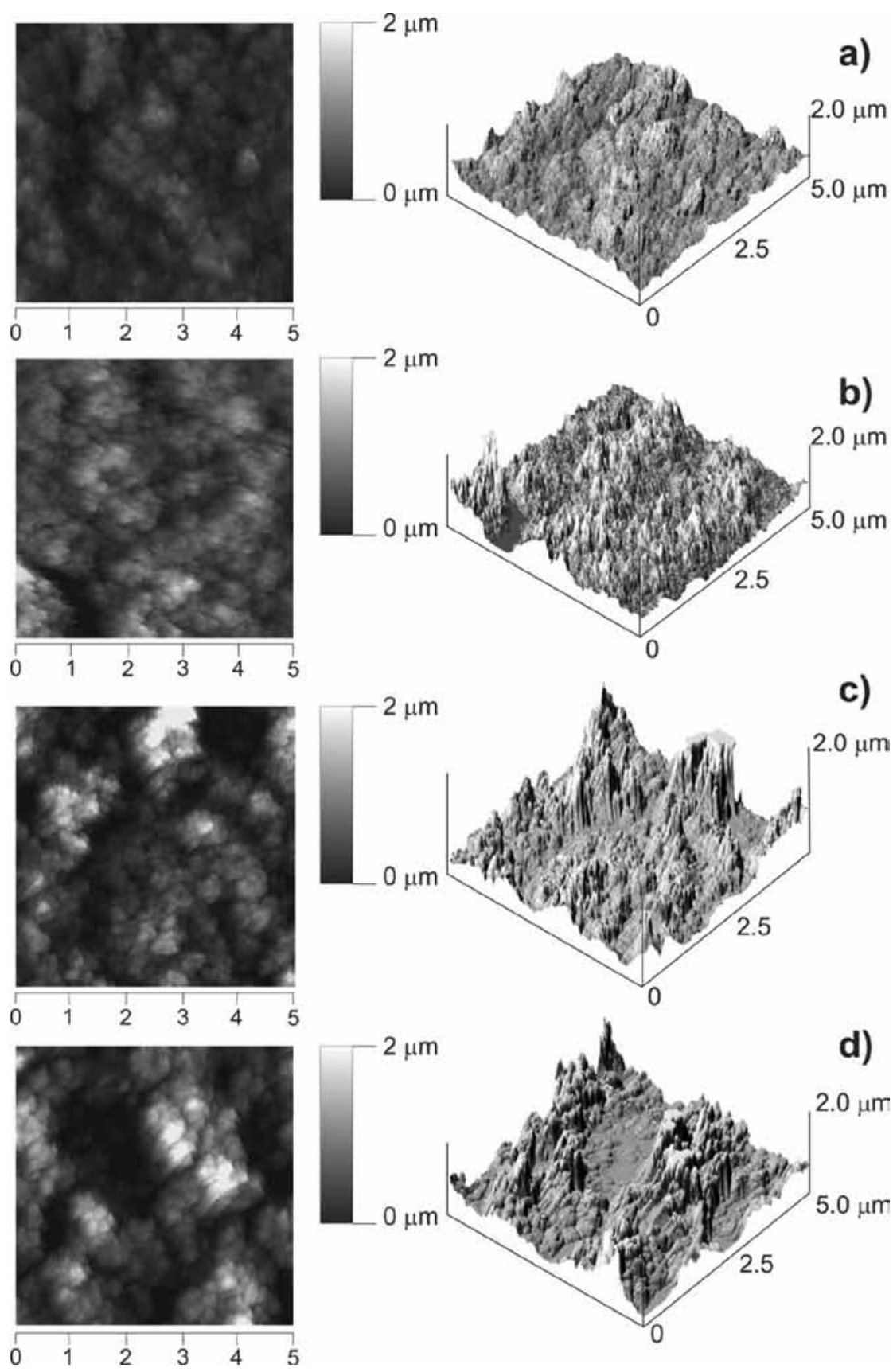

Fig. 2. Two- and three-dimensional AFM images of $\mathrm{TiO}_{2}$ thin films: as-prepared (a), and annealed at $500{ }^{\circ} \mathrm{C}(\mathrm{b}), 600{ }^{\circ} \mathrm{C}$ (c), and $700{ }^{\circ} \mathrm{C}$ (d)

the increase of annealing temperature up to $500{ }^{\circ} \mathrm{C}$ (Figure 3 ), whereas the roughness of the $\mathrm{TiO}_{2}$ films thermally treated at 500 and $600{ }^{\circ} \mathrm{C}$ remains unchanged. Further annealing of the samples up to $700{ }^{\circ} \mathrm{C}$ causes notable changes in topography and roughness due to the agglomeration of $\mathrm{TiO}_{2}$ particles on the surface.

In addition to the surface roughness, thin film fractal dimensions were also estimated by using AFM images. The texture of an image is the attribute representing the spatial arrangement of the gray levels of the pixels, which quantifies the visual characteristics within the image as the roughness and smoothness of the object. Shifting Differential Box Counting (SDBC) algorithms have been used widely to estimate the fractal dimension values. The SDBC algorithm, based on the surface intensity plot 
(Figure 2; 3D AFM images), is generated from 2D grayscale AFM images. This is performed

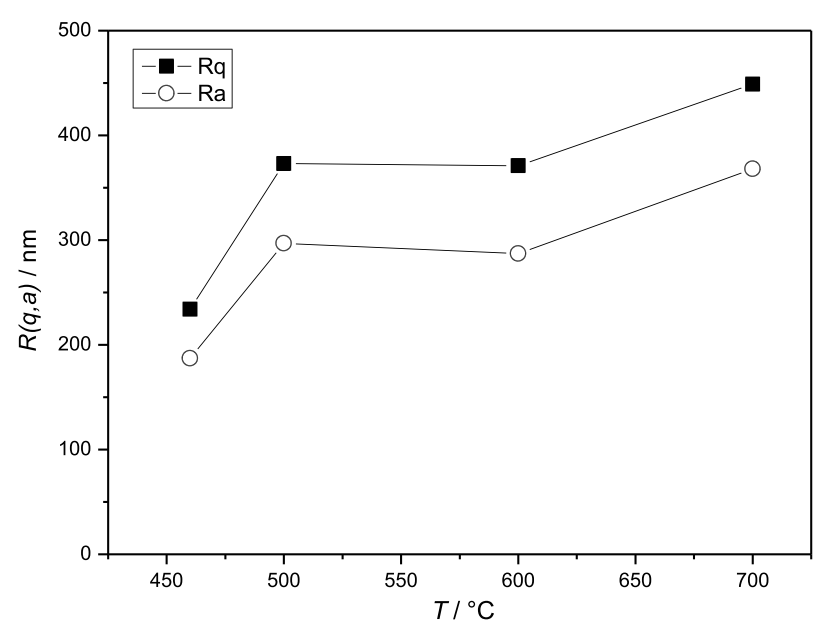

Fig. 3. Plot of annealing temperature versus roughness $\left(\mathrm{R}_{\mathrm{a}}\right.$ and $\left.\mathrm{R}_{\mathrm{q}}\right)$ of the as-prepared $\mathrm{TiO}_{2}$ thin films $\left(460{ }^{\circ} \mathrm{C}\right)$, and films annealed at various temperatures $\left(500,600\right.$, and $\left.700{ }^{\circ} \mathrm{C}\right)$ by plotting pixel coordinates $(x, y)$ and the gray level plotted in the $z$-axis [24]. The fractal dimension was estimated from the slope in the $\log$ (box count) versus log (box size) plot and by the following equation:

$$
D=\frac{\log N}{\log \left(\frac{1}{r}\right)},
$$

where $N$ is the number of boxes and $r$ is the length of the side box or box size. The slope of the straight line fitted to the plotted points represents the fractal dimension of the surface of the investigated $\mathrm{TiO}_{2}$ films.

The fractal dimension of the morphology of the as-prepared and annealed samples are calculated from the slopes of the curves shown in Figure 4.

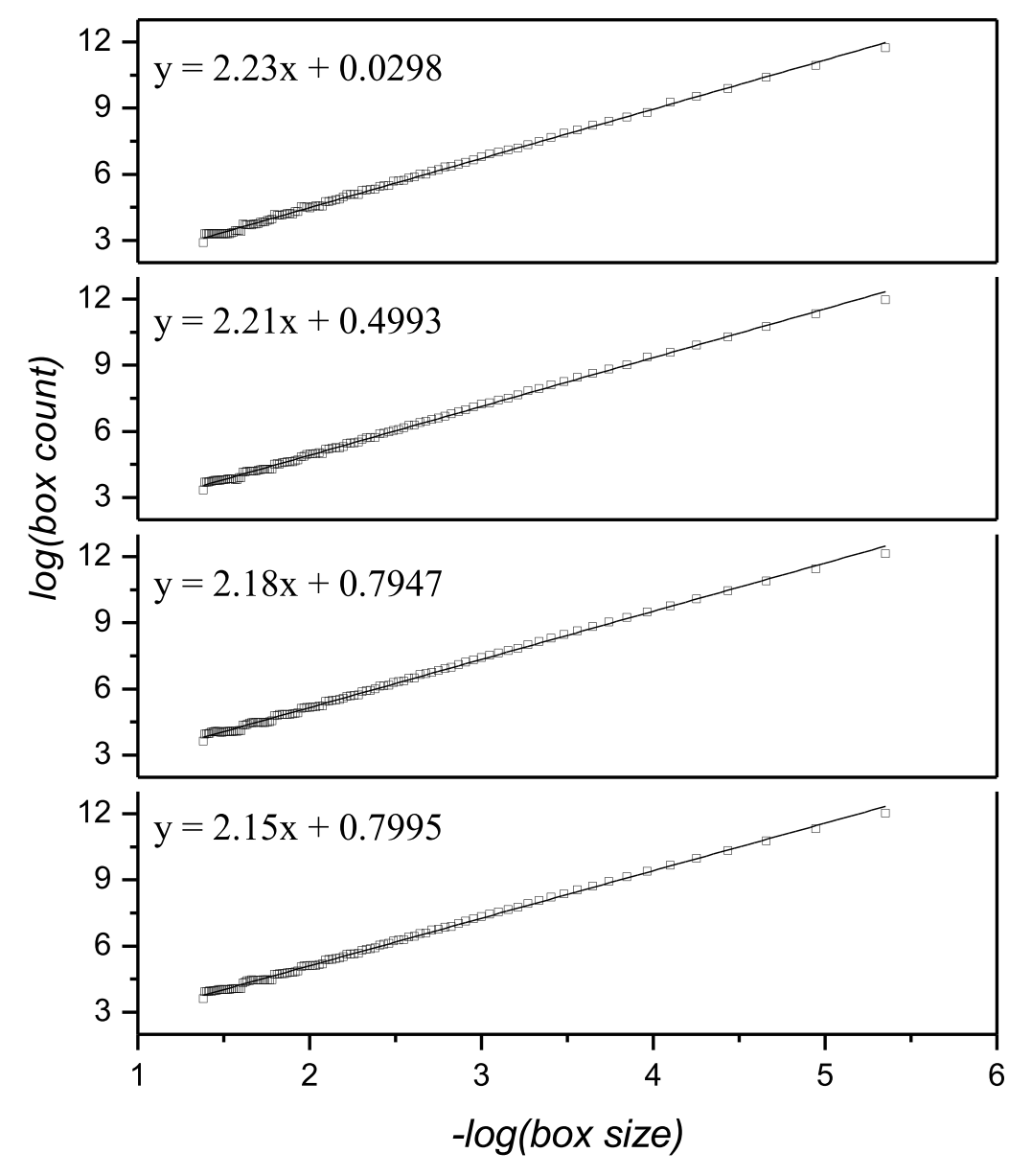

Fig. 4. Typical plots illustrating calculation of fractal dimension by SDBC method 
Fractal analysis has shown that all samples exhibit a self-similar character, which is a consequence of the deposition process and is moderately sensitive to the annealing temperature. The as-prepared samples have a higher fractal dimension than the subsequently annealed $\mathrm{TiO}_{2}$ thin films.

A plot of the annealing temperature versus the values of the fractal dimension of the $\mathrm{TiO}_{2}$ films is shown in Figure 5. It is clear from the plot that on annealing, the calculated values of the fractal dimension decrease to 2.21 ( \pm 0.0087$), 2.18( \pm 0.0092)$, and $2.15( \pm 0.0088)$, at 500,600 , and $700{ }^{\circ} \mathrm{C}$, respectively.

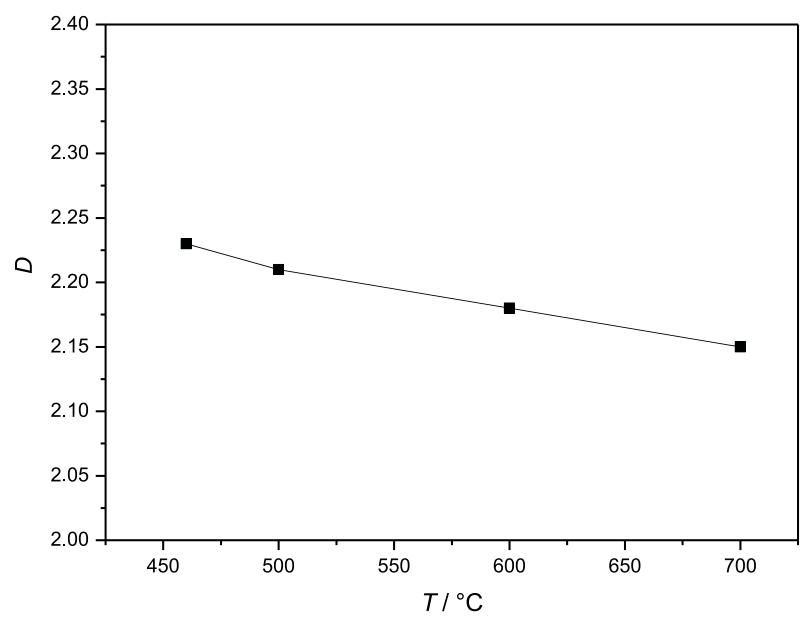

Fig. 5. Plot of annealing temperature versus fractal dimension of the as-prepared $\mathrm{TiO}_{2}$ thin films $\left(460{ }^{\circ} \mathrm{C}\right)$, and films annealed at various temperatures $\left(500,600\right.$, and $\left.700{ }^{\circ} \mathrm{C}\right)$

Heat treatment results in lowering the surface energy of the films owing to thermodynamic action, which decreases the irregularity of the film surfaces [25]. Contrary to our expectation, a relationship between the fractal dimension and roughness parameter was not observed. The different behavior of these parameters can be explained by the fact that the fractal dimension reflects largely the complexity of the thin film surface rather than its roughness.

Photocatalytic tests showed (Table 2) that photoactivity gradually decreases with an increase of annealing temperature. A slight drop in photoactivity is observed for the as-prepared samples and those annealed at $500{ }^{\circ} \mathrm{C}$. Further annealing to $600{ }^{\circ} \mathrm{C}$ leads to an unexpectedly significant drop in activity, whereas annealing at $700{ }^{\circ} \mathrm{C}$ results in almost the disappearance of photoactivity.

Table 2

$$
\begin{gathered}
\text { Apparent first-order constants }\left(k_{\text {app }}\right) \text { for } \\
\text { photocatalytic degradation of arylazo } \\
\text { pyridone dye using } \mathrm{TiO}_{2} \text { films. }
\end{gathered}
$$

\begin{tabular}{lcc}
\hline \hline Film & $\begin{array}{c}\text { Annealing temperature } \\
\left({ }^{\circ} \mathrm{C}\right)\end{array}$ & $\begin{array}{c}k_{\text {app}}, \\
\left(\mathrm{h}^{-1}\right)\end{array}$ \\
\hline As-prepared & 460 & 0.308 \\
$\mathrm{TiO}_{2}(\mathrm{P} 25)_{500}$ & 500 & 0.241 \\
$\mathrm{TiO}_{2}(\mathrm{P} 25)_{600}$ & 600 & 0.089 \\
$\mathrm{TiO}_{2}(\mathrm{P} 25)_{700}$ & 700 & 0.004 \\
\hline \hline
\end{tabular}

The observed reduction in the photocatalytic activity of the samples after annealing may be caused by changes in the crystal structure, textural properties, and surface morphology of the films. The roughness, phase composition, and crystallite size of the sample annealed at $600{ }^{\circ} \mathrm{C}$ are almost unchanged compared with the sample annealed at $500{ }^{\circ} \mathrm{C}$. Therefore, other factors should be considered. Most likely, the stainless steel support plays a significant role in the drop of the photocatalytic activity at 600 and $700{ }^{\circ} \mathrm{C}$. In our previous study [9], we investigated the behavior of stainless steel substrate covered by $\mathrm{TiO}_{2}$ film at different temperature regimes. The XPS analysis revealed that Fe and $\mathrm{Al}$ ions diffuse from the support into the $\mathrm{TiO}_{2}$ film layer after annealing above $600{ }^{\circ} \mathrm{C}$. It is well known that the presence of metal ions, which are formed in the thermo-diffusion process, can change the film stoichiometry and increase $\mathrm{e}^{-} / \mathrm{h}^{+}$recombination; thus, reducing photodegradation rate. This process is intensified at $700{ }^{\circ} \mathrm{C}$ with an increasing weight fraction of the rutile phase up to $42.6 \%$. Literature data point out that the increase of fractality follows a more efficient degradation due to the increase of the surface available for light adsorption [13]. This 
is in accordance with the obtained results of the fractal dimension, which decreases from 2.23 to 2.15 with increasing annealing temperature.

\section{CONCLUSIONS}

Thin films of $\mathrm{TiO}_{2}$ (Degussa-P25) were prepared by spray deposition method. $\mathrm{TiO}_{2}$ films were further annealed at various temperatures $\left(500,600\right.$, and $\left.700{ }^{\circ} \mathrm{C}\right)$ and characterized by XRD and AFM. The phase composition of the as-prepared samples and samples annealed at 500 and $600{ }^{\circ} \mathrm{C}$ corresponds to the phase composition of the initial $\mathrm{TiO}_{2}$ (Degussa-P25), whereas annealing at $700{ }^{\circ} \mathrm{C}$ increases the rutile content significantly.

The fractal dimension and roughness of the $\mathrm{TiO}_{2}$ thin films surfaces were estimated from the AFM images. The surface roughness of the thin films changes slightly with the increasing temperature up to $600{ }^{\circ} \mathrm{C}$. At the higher annealing temperature of $700{ }^{\circ} \mathrm{C}$, particularly in the region of the anatase-to-rutile transformation, a significant change of roughness was observed. The results of the fractal analysis revealed that both the as-prepared and annealed samples possess fractal properties, and that increasing annealing temperature leads to a decrease in the irregularity of the surface.

Acknowledgments. This work was supported by the Ministry of Education and Science of the Republic of Serbia (Projects number 172001, 172015, 171035, 172022 and 172026).

\section{REFERENCES}

[1] A. Fernández, G. Lassaletta, V. M. Jiménez, A. Justo, A. R. González-Elipe, J.-M. Herrmann, H. Tahiri, Y. Ait-Ichou, Preparation and characterization of $\mathrm{TiO}_{2}$ photocatalysts supported on various rigid supports (glass, quartz and stainlesssteel). Comparative studies of photocatalytic activity in water purification, Appl. Catal. B-Environ., 7, 49-63 (1995).
[2] W. Zhang, K. Wang, Y. Yu, H. He, TiO 2 /HZSM5 nano-composite photocatalyst: $\mathrm{HCl}$ treatment of NaZSM-5 promotes photocatalytic degradation of methyl orange, Chem. Eng. J, 163, 62-67 (2010).

[3] N. Rao Neti, G. Rani Parmar, S. Bakardjieva, J. Subrt, Thick film titania on glass supports for vapor phase photocatalytic degradation of toluene, acetone, and ethanol, Chem. Eng. J, 163, 219-229 (2010).

[4] G. Balasubramanian, D. D. Dionysiou, M. T. Suidan, I. Baudin, J.-M. Laine, Evaluating the activities of immobilized $\mathrm{TiO}_{2}$ powder films for the photocatalytic degradation organic contaminants in water, Appl.Catal. B-Environ., 47, 73-84 (2004).

[5] H. D. Jang, S. K. Kim, S.-J. Kim, Effect of particle size and phase composition of titanium dioxide nanoparticles on the photocatalytic properties, $J$. Nanopart. Res., 3, 141-147 (2001).

[6] Y. Chen, D. Dionysiou, A comparative study on physicochemical properties and photocatalytic behavior of macroporous $\mathrm{TiO}_{2}$ - P25 composite films and macroporous $\mathrm{TiO}_{2}$ films coated on stainless steel substrate, Appl. Catal. A-Gen., 317, 129-137 (2007).

[7] A. I. Kontos, A. G. Kontos, D. S. Tsoukleris, M. C Bernard, N. Spyrellis, P. Falaras, Nanostructured $\mathrm{TiO}_{2}$ films for DSSCS prepared by combining doctor-blade and sol-gel techniques, J. Mater. Process. Tech., 196, 243-348 (2008).

[8] C. Trapalis, N. Todorova, M. Anastasescu, C. Anastasescu, M. Stoica, M. Gartner, M. Zaharescu, T. Stoica, Atomic force microscopy study of $\mathrm{TiO}_{2}$ sol-gel films thermally treated under $\mathrm{NH}_{3}$ atmosphere, Thin Solid Films, 517, 6243-6247 (2009).

[9] J. Dostanić, B. Grbić, N. Radić, P. Stefanov, Z. Šaponjić, J. Buha, D. Mijin, Photodegradation of an azo pyridone dye using $\mathrm{TiO}_{2}$ films prepared by the spray pyrolysis method, Chem. Ing. J., 180, (2012) 57-65.

[10] A. De Giacomo, V. A. Shakhatov, G. S. Senesi, S. Orlando, Spectroscopic investigation of the technique of plasma assisted pulsed laser deposition of titanium dioxide, Spectrochim. Acta B, 56, 14591472 (2001).

[11] W. Guo, J. F. Porter, Ch. M. Chan, Ch. K. Chan, Characterization of ultrafine titanium dioxide powders produced by vapor phase hydrolysis of titanium tetraisopropoxide, J. Aerosol Sci., 28, S485-S486 (1997). 
[12] M. A. Khadar, N. A. M. Shanid, Nanoscale finestructure evaluation of RF magnetron sputtered anatase films using HRTEM, AFM, micro-Raman spectroscopy and fractal analysis, Surf. Coat. Tech., 204, 1366-1374 (2010).

[13] A. P. Xagas, E. Androulaki, A. Hiskia, P. Falaras, Preparation, fractal surface morphology and photocatalytic properties of $\mathrm{TiO}_{2}$ films, Thin Solid Films, 357, 173-178 (1999).

[14] W. Kwaśny, L. A. Dobrzański, Structure, physical properties and fractal character of surface topography of the $\mathrm{Ti}+\mathrm{TiC}$ coatings on sintered high steel, J. Mater. Process. Tech., 164-165, 1519-1523 (2005).

[15] A. Mannelquist, N. Almqvist, S. Fredrikson, Influence of tip geometry on fractal analysis of atomic force microscopy images, Appl. Phys. A Mater., 66, S891-S895 (1998).

[16] F. Feng, K. Shi, S.-Z.Xiao, Y.-Y. Zhang, Z.-J. Zhao. Z. Wang, J.-J. Wei, Z. Han, Fractal analysis and atomic force microscopy measurements of surface roughness for Hastelloy C276 substrates and amorphous alumina buffer layers in coated conductors, Appl. Surface Sci., 258, 3502-3508 (2012).

[17] E. S. Gadelmawla, M. M. Koura, T. M. A. Maksoud, I.M. Elewa, H.H. Soliman, Roughness parameters, J. Mater. Process. Tech., 123, 133-145 (2002).

[18] J. B. Florindo, M. S. Sikora, E. C. Perira, O. M. Bruno, Characterization of nanostructured material images using fractal descriptors, Physica A, 392, 1694-1701 (2013).
[19] S. Stojadinović, N. Radić, R. Vasilić, M. Petković, P. Stefanov, Lj. Zeković, B. Grbic, Photocatalytic properties of $\mathrm{TiO}_{2} / \mathrm{WO}_{3}$ coatings formed by plasma electrolytic oxidation of titanium in 12-tungstosilicic acid, Appl. Catal. B Environ., 126, 334-341 (2012).

[20] C. Tealdi, E. Quartarone, P. Galinetto, M. S. Grandi, P. Mustareli, Flexibile deposition of $\mathrm{TiO}_{2}$ electrodes for photocatalytic application: Modulation of the crystal phase as a function of the layer thickness, J. Solid State Chem., 199, 1-6 (2013).

[21] T. Novaković, N. Radić, B. Grbić, T. Marinova, P. Stefanov, D. Stojčev, Oxidation of n-hexane over $\mathrm{Pt}$ and $\mathrm{Cu}-\mathrm{Co}$ oxide catalysts supported on a thinfilm zirconia/stainless steel carrier, Catal. Commun., 9, 1111-1118 (2008).

[22] R. W. G. Wyckoff, Crystal Structures, 1. Second edition, Interscience Publishers, New York, 1963, pp. 239-444.

[23] S. Bakardjieva, J. Šubrt, V. Štengla, M. J. Dianez, M. J. Sayagues, Photoactivity of anatase-rutile $\mathrm{TiO}_{2}$ nanocrystalline mixtures obtained by heat treatment of homogeneously precipitated anatase, Appl. Catal. B Environ., 58, 193-202 (2005).

[24] C. Wen-Shiung, Y. Shang-Yuan, H. Chih Ming, Two algorithms to estimate fractal dimension of grey-level images, Optical Engineering, 42(8), 2452-2464 (2003).

[25] K. T. Lam, L. W. Ji, Fractal analysis of InGaN selfassemble quantum dots grown by MOCVD, $\mathrm{Mi}$ croelectron. J., 38, 905-909 (2007). 
